\title{
Lactivism and Mothering as Libertarian Social Practices: A Feminist Plea
}

\author{
Ester Massó Guijarro \\ Department of Philosophy I, University of Granada, Granada, Spain.
}

How to cite this paper: Ester Massó Guijarro. (2022) Lactivism and Mothering as Libertarian Social Practices: A Feminist Plea. Journal of Humanities, Arts and Social Science, 6(1), 43-49.

DOI: $10.26855 /$ jhass.2022.01.004

Received: November 29, 2021

Accepted: December 26, 2021

Published: January 24, 2022

*Corresponding author: Ester Massó Guijarro, Department of Philosophy I, University of Granada, Granada, Spain. Email: ester@ugr.es

\begin{abstract}
These are turbulent times, days of crisis and transformation, days in which many people try to change the world in many different ways. Social movements in which the public sphere is taken from the margins, with new ways of politics-namely, of entering the public arena-aiming at changing the world, seeking to achieve greater justice and express outrage at injustice. In the 1990s, the Mexican Zapatista revolution's battle cry was the idea of changing the world without taking the power. That is to say: governmental power. The phrase and the idea had such an impact that they ended up in a book, which became a reference in social sciences: Change the world without taking power, written by John Holloway. The author studied the Zapatista movement; how structures for action and thought needed to be changed to enable a fairer world, not necessarily by traditional policies (political parties, representative government...). Thus, we find vibrant and telling examples of how to change the world without taking the power, of how to engage in politics from the grassroots, of how to start a revolution from the crib (from the arms!), in the most literal sense, in the relentless daily activity of breastfeeding and parenting support groups. Because, if we begin to raise from the base, and mothering children, future people-thus, the future base of society, in a respected and emotionally stable way, we will be laying the first foundations for pacific, diverse and respectful societies. Such groups and the people that give life to them are also a striking example of the catch phrase across the field of social struggles for alter-globalization as a means to build a fairer world: "think global, act local”. These groups, which have a marked horizontal nature-non-adultocentric — change the world without taking power. Even though we may actually empower ourselves in different ways, we think globally when we act locally, every day, with our children.
\end{abstract}

\section{Keywords}

Breastfeeding, Children, Feminism, Social-Political Movement, Mothering

\section{Introduction: breastfeeding, mothering, caring, as feminist actions ${ }^{1}$}

These are turbulent times, days of crisis and transformation, days in which many people try to change the world in many different ways. Social movements in which the public sphere are taken from the margins, with new ways of politics—namely, of entering the public arena-aiming at changing the world, seeking to achieve greater justice

\footnotetext{
${ }^{1}$ The following reflections constitute a synthetic compendium of various public interventions and previous papers of the author (due to this, the bibliography cited is almost entirely by the author). A summary of these papers was communicated in the VIII International Conference on Critical Education, celebrated at the University of East London, Stratford (London, England), 25th-28th July, 2018.
} 
and express outrage at injustice.

In the 1990s, the Mexican Zapatista revolution's battle cry was the idea of changing the world without taking the power. That is to say: governmental power. The phrase and the idea had such an impact that they ended up in a book, which became a reference in social sciences: Change the world without taking power, written by John Holloway. The author studied the Zapatista movement; how structures for action and thought needed to be changed to enable a fairer world, not necessarily by traditional policies (political parties, representative government...).

Thus, we find vibrant and telling examples of how to change the world without taking the power, of how to engage in politics from the grassroots, of how to start a revolution from the crib (from the arms!), in the most literal sense, in the relentless daily activity of breastfeeding and parenting support groups. Because, if we begin to raise from the base, and mothering children, future people -thus, the future base of society-, in a respected and emotionally stable way, we will be laying the first foundations for pacific, diverse and respectful societies (Massó Guijarro, 2015a; Massó Guijarro, 2015b).

Such groups and the people that give life to them are also a striking example of the catch phrase across the field of social struggles for alter-globalization as a means to build a fairer world: "think global, act local”. These groups, which have a marked horizontal nature-non-adultocentric — change the world without taking power. Even though we may actually empower ourselves in different ways, we think globally when we act locally, every day, with our children.

In addition, in this process, we are acknowledging people from their origins: pregnancy, delivery, and early childhood. Even when they do not have a 'public voice', because they are not political subjects yet, they are indeed legal subjects and have human rights (Massó Guijarro, 2015c). Such rights are realised, with babies and in early childhood, in the form of shelter and protection, with absolute respect from caregivers, constant comfort, the right not to be left in a dark room (not even at night), the right not to be fed with substitute foods if possible, the right not to be trained with behavioural techniques to adapt (and disrupt) sleep patterns for the convenience of caregivers, the right to be free from affective and sensorial privation, the right to be raised in non-submission. If we teach our own children submission and resentment from birth, we should not expect equal, fair and combative, societies. This is caring, in one word. It is a fight for democracy and for a socio-political caring that comes "from the belly", from the breasts, from the arms, from home, from the streets.

So as to explain these ideas, I will reflect on breastfeeding as a central element in mothering, as a place for feminist social transformation, where breastfeeding mums and their environment are capable of creating altruism and social cooperation, both at micro and macro levels (Personally with each baby and with society at large, respectively) (Massó Guijarro, 2015a; Massó Guijarro, 2015b).

I will claim breastfeeding as a central issue on the feminist agenda, as it is beneficial not only to infants but also to their mothers, and society at large. For this reason, we will defend breastfeeding in particular and mothering in general as highly beneficial in a holistic way: physiological, emotional, and social.

Breastfeeding will be addressed here, thus, as a core element in a set of practices clustered around it, including: pregnancy, delivery, extero-gestation (through breastfeeding) (Massó Guijarro, 2013b), and finally, raising children, all carried out with attachment style. All of the above is expressed through the term "mothering”. Mothering means "to perform motherhood" in such a way, with the "attachment" described here. Mothering is not exclusively female; a man can also mother, any person can regardless of their gender. However, we do not use "fathering" or "fatherhood" because attachment parenting has been carried out by women throughout centuries and cultures. We want to honour motherhood as a practice that, like breastfeeding, has been undervalued and unrecognized in Western culture (no useful work, no knowledge, no wisdom in it...), except from its physiological dimension, if you will.

Mothering and care are-always-politics, in the sense of social transformation and intervention, of collectively occupying public spaces. It is time to establish, or better, to recognise such political dimension of care in the upbringing of children, of engaged mothering; attached, respectful with human rights. Mothering as a pleasure, but always and justly, as a right.

I will reflect upon breastfeeding addressed from an interdisciplinary perspective, in order to claim breastfeeding as a place/locus for feminist social transformation, where breastfeeding mothers and their environment are capable of creating altruism and social cooperation, both at micro (personally with each baby) and macro (with society at large) levels, as stated before. The end aim is to claim breastfeeding as an object of study relevant to social sciences and arts, on the one hand, and as a feminist goal, on the other. Having said that, I should clarify that in this paper, I will focus on Western societies, because it is there where lies the concept of family and gender serving as the basis 
for epistemological domination on the matter of lactation (Massó Guijarro, 2013a).

\section{Breastfeeding's herstory ${ }^{2}$}

Since the mid-twentieth century, in the Western world, there has been a link between breastfeeding and patriarchal social restraints binding women to the household, on the basis of a merely reproductive naturalistic conception of women. However, today we find a reappraisal of breastfeeding from different angles, including feminism. Perspectives of social sciences highlight benefits of breastfeeding not only to the baby, but in particular, to the mother (from the holistic point of view defended by the World Health Organization-WHO). In fact, non-breastfeeding is not only detrimental to the baby but also to the mother, precisely in this respect non-breastfeeding has a quite different meaning, contrary to liberation, it represents a significant detriment to women's health, as it is deeply rooted in patriarchal oppression (Massó Guijarro, 2013a).

There is a need to address a sort of epistemological shielding against breastfeeding prejudices. Incidentally, such prejudices underpin the fallacies present in many critical approaches to breastfeeding from certain feminist quarters. Hence, I maintain that such prejudices are deeply rooted in patriarchal reason, although often disguised as some certain feminisms. The historiography of breastfeeding can be defined, in sum, as a patriarchal account, in the sense that: a) it has been reduced to exclusively feminine discourse or reality (further taking for granted the hegemonic conception of the feminine gender as a straight woman), when in fact it comprises more broader social contexts and their consequences; b) it has been restricted to an exclusively feminine area. Consequently, it has been socially discredited and deemed as a private and domestic activity, deprived of valuable factors in a socioeconomic, public or ethic perspective (Massó Guijarro, 2013b).

The present reflection is part of a broader research project, and it is devoted to challenging this patriarchal account on breastfeeding from different places and disciplines, on the one side, and on the other, empirically examining the feminist lactivist movement. I will further introduce breastfeeding as a politics of the body that binds dissident breastfeeding corporealities. In this sense, with each breastfeeding practice, socially encompassed and signified, activists dissent from the late capitalistic normativities of individualism, working productivity (full time) and the public-private and productive/non-productive (discredited in substantivist approaches to economic anthropology, such as Polanyi's work, and some feminist anthropologist) boundaries/divisions.

In this work, there is also an inescapable, cutting-edge, element of vindication. Terms such as non-submission, dissidence, heteronormativity are tactically used to recognize other realities from different standpoints. Thus, our aim is to build a foundation for pluralistic epistemologies and to move towards them through different human and social spheres.

Nowadays, the WHO promotes exclusive breastfeeding for at least 6 months, complementary breastfeeding until age 2, or up until the mother or the baby wish to stop. Plainly, breastfeeding in post-industrial societies is found to be incompatible with work activity (outside the home), considering the spatiotemporal inflexibility in the capitalist production, and its assimilation of social prestige to the production of monetary wealth.

Breastfeeding, like other human phenomena, cannot be brought within the purely physiological or bodily boundaries. To put it another way, its corporeality cannot be self-explanatory-merely in a reference to the flesh-despite the importance of the flesh in breastfeeding. Thus, like any other human phenomena, it is culturally determined. So far, the meanings attributed to breastfeeding from a critical perspective, have not been positive, especially since women's entry into the labour market (capitalist, industrial, monetarised) has constituted a major feminist goal. When the distinction between public and private spaces solidified in industrial production, the breast was confined per se to the private sphere, to the household. Evidently, in binary or dual systems one part falls into disgrace (and we very well know which is which in this case). Thus, the private and domestic space came to be considered of lesser social prestige than its public counterpart. Hence, breastfeeding was never considered prestigious (actually, quite the opposite, as illustrated by the fact that upper-class women had a wet nurse when they could afford one).

When considering what steps to take towards women's emancipation, we tend to look at things only from one side. If public spaces and remunerated work have enjoyed social prestige so far, women have to occupy them on an equal footing. However, we argue that a radically more feminist, vindicatory, and emancipatory objective would be that activities traditionally attributed to women enjoyed the same prestige and relevance as men's activities. We

${ }^{2}$ In the sense that we use the concept of hooks (hooks et al., 2010) in my research about lactation (Massó Guijarro, 2018). See also Massó Guijarro (2017a,b; 2021, 2020) and Massó Guijarro\&Triviño Caballero (2020). 
should claim the importance of what takes place at home, to the extent that we demand that men accept equal responsibility for the household. This way we could dissolve the poor capitalistic public/private distinction. It is at home where we raise and teach children, thus, where we build the early emotional foundation of citizenry (see for example Isasi-Díaz, 2003).

Today we claim that men need to take on caregiving, too. This division of tasks should not be deemed as a sacrificial sentence that needs to be shared, but rather as a source of values that enriches people's lives. In fact, promoting childcare values, without gender distinction, is relevant in itself. Furthermore, caregiving responsibilities can be shared between different people at different stages of the life cycle, contributing to a greater social and personal enrichment, and providing an improvement in social sustainability.

What is crucial in this reflection is babies' perspective, which has been increasingly disregarded. The reasons for this oblivion are studied under the term 'adultocentrism'. Akin to sexism and racism, adultocentrism implies discrimination on grounds of age. It imposes a certain cosmovision, organization, and norms, de-legitimizing all that is different (in this case, being a baby). Against adultocentrism, babies' perspective is sustained from different standpoints: ethics of interests and advocacy for rights. On this basis, we must bear in mind that babies also have preferences or choices, even though they cannot express them verbally and, hence, cannot be political actors. In this light, breastfeeding is probably one of their fundamental interests, as well as physical contact and cuddling (especially in their early months and years), also at night, thus implying co-sleeping, necessarily (Massó Guijarro, 2015c).

\section{On lactivism: the socio-political transcendence of lactation}

Lactivists are people who transform the social categories attributed to breastfeeding and, in doing so, create cooperative networks. Altruism and mutual solidarity illustrate the revolutionary potential of breastfeeding both at micro (personal) and macro (social) levels. Lactivists are breastfeeding activists: they are activists while they breastfeed, not in different moments or at different spaces. That is to say, their political struggle happens spatiotemporally undifferentiated from that of their suckling infants. In this sense, they always act together with their babies and not without them; it is not a heavy burden, but a positive value, to the extent that their meetings and activities insist on the fact that 'children and babies are welcome'. Thus, a process of reappropriation of a traditionally feminine space takes place, culturally re-signifying it (Massó Guijarro, 2015a; Massó Guijarro, 2015b).

The decline in breastfeeding that began around the 1950s-60s in the Western world is understood as the disempowerment of women resulting from the alliance between patriarchy and capital, as opposed to a feminist achievement. This scenario is analogous to mother disempowerment at birth, since the irruption of medical values led to some setbacks and failures such as an increased risk of maternal and perinatal death. Nowadays, the association "The Birth is ours" 3 runs a research group on obstetric violence as a newly recognised form of gender violence, which takes place regularly, inadvertently, and with acceptance in Spanish delivery rooms, and elsewhere (Massó Guijarro, 2015a; Massó Guijarro, 2015b).

Lactivism implies the reinvention of breastfeeding through the social transformation it triggers, cited here as a grounds for the attribution of new meanings to breastfeeding as a feminist practice. That is to say, lactivism is a reinvention of breastfeeding adapted to the societies and historical moments that we live in. We use its critical and transformative potential as a bio-cultural human activity.

"This is my lactation room" is the slogan printed on bags many breastfeeding women carry in the streets as a symbol. An apparent support of breastfeeding has led to the spread of lactation rooms in public spaces, shopping centres, etc. The presence of such rooms is considered a double-edged sword, as evidenced by the political slogan printed on the bags mentioned. Even though it is true that some women prefer privacy when they breastfeed, lactation rooms may have a much less friendly face, meaning that 'it cannot be done in public'. The room turns something that should be simply spontaneous — and that among other aspects, meets a major need—into a prison. Sadly, there is the infamous case of a woman who was told by the security guard to stop breastfeeding her baby in a restaurant in an Andalusian shopping centre, because there was a lactation room at the premises. The place presented as a favourable permission is in fact a confinement. Thus, most lactivists prefer to breastfeed in public, where they are in that moment, because it is more comfortable (practical reason), and, of course, more dignified (political reason) (Massó Guijarro, 2013a).

Some women do prefer the privacy of lactation rooms for reasons such as that in public they feel libidinously

\footnotetext{
3“El parto es nuestro” in Spanish (https://www.elpartoesnuestro.es/).
} 
observed by men. This fact constitutes, I believe, one more instrument of oppression and symbolic violence: that a breastfeeding mother is to feel intimidated while breastfeeding in public because, there are, indeed, breastfeeding voyeurs. (In this presentation we cannot illustrate further on the many and various dissuasive, oppressive, and intimidatory acts against breastfeeding in public).

There are many diverse fallacies around breastfeeding, not only physiological, but psychological and social, rooted in patriarchy and capitalism - in this case, coming from the pharmaceutical industry. These false premises include myths such as weight gain during breastfeeding (of course, there is no greater disgrace in this frivolised Western society than gaining weight, not to mention being obese), breast ptosis or sagging, total dependence of the baby on the mother, etc. At the base of these fears we find women's subordination to men as objects of desire. We reject the breast to feed babies because it provokes dependence of the baby and sagging, and then, we accept them as aesthetic-sexual objects for men, and preserve them for men. The acceptance of this argument is greater than it seems. In this sense, the breast as a sexual object is more positively considered in a context of compulsive heterosexism (let us not forget, of subordination to men, especially) than as a secreting gland and a source of food; or as a sexual object for women themselves and their babies, to put it another way, given the fact that a milk-ejecting breast is too sexual, de facto (but it is not intended for men) (Massó Guijarro, 2013b).

With the recognition of sexuality inherent in breastfeeding, such a discourse reveals itself in its fullness as the repression of sexuality and subjugation, even disguised with a shade of liberation. Whenever we access verified data on objective aspects of women's health related to breastfeeding, this issue is further aggravated. If it were a serious men's health issue, probably no man would sacrifice his health (not to mention sex) to other interests. Breastfeeding is associated to relevant health benefits such as faster and better recovery after birth, (baby's suckling provokes uterine contractions that prevent post-partum haemorrhages), prevention of breast cancer and ovarian cancer, prevention of osteoporosis, prevention of postpartum depression, best adaptation to new motherhood, and finally, a decreased medication use by both the mother and the child, according to data evidencing (bio-psychosocial) health improvement through breastfeeding, especially the prolonged one (two years or longer). Further benefits, not included here, are the emotional bonds with their babies, most valued by lactivists. Regarding breastfeeding difficulties that many sectors raise against it, these are always rooted in the lack of appropriate support and counselling to new mothers. This means failure of the State, public administrations and health institutions (Massó Guijarro, 2013a).

\section{Final plea: lactation, rebellion, revolution}

I cannot help but to see a deeply patriarchal action underlying the question "Will you breastfeed the baby or shall I give you the pill?” that even today's midwives ask new mothers in many public and private hospitals. Herculean newcomers sweating, shaking, after fighting Hydra ${ }^{4}$. Because, first of all, suggesting the use of this pill may imply total professional incompetence, given the fact that midwives' work is to advice new mothers on healthcare issues in the best way possible (and not to suggest the use of the pill ${ }^{5}$, a medicine intended to alter a perfectly healthy physiological secretion), and apart from the fact that such a suggestion may even be reported to medical authorities, I can only think that such suggestions and questions would not exist if breastfeeding was a male thing. Such wonderful nutritious capacity, formative, citizenising, pacifying, integrating, sexually rooted... would have an anthem, would be declared an intangible heritage of humanity, there would be odes dedicated to breasts, and of course extended breastfeeding leaves (all paid for)... and finally, there would be no pills to inhibit breastmilk production (if at all, to stimulate it) (Massó Guijarro, 2013a).

Lactation is revolution, just like giving birth is a journey and a feat. We demand breastfeeding as a place for revolution and cultural insubordination, colostrum as the hotbed for this revolution, and caregiving as a value that transcends the boundaries between public and private and extends itself in interconnected trans-politics of globalization (Massó Guijarro, 2013a).

\footnotetext{
${ }^{4}$ We echo the beautiful metaphor recreated by Leboyer (1998) about childbirth as a Homeric narrative. We can also remember how the narratives of the cuna in Panama helped the positive evolution of dystocic births: in general, any symbolic or poetic narration that gives cosmos, meaning and dignity to a physical pain, in principle formless, can transform suffering into operability and effectiveness, even empowerment.

${ }^{5}$ Anonymous lactivist interlocutors comment how this was the first question that their midwife asked them in the delivery room after giving birth. The "pill" is a drug (Bromocriptine or Cabergoline) to inhibit the production of breastmilk and that must be administered under strict medical supervision.
} 


\section{References}

Hooks, bell, et al. (2010). Other inappropriables: feminisms from the frontiers. Madrid: Traficantes de sueños.

Isasi-Díaz, Ada María. (2003). The everyday, intrinsicelement of reality. In R. Fornet-Betancourt (Ed.), Resistance and solidarity. Capitalist globalization and liberation (pp. 365-384). Madrid: Trotta.

Massó Guijarro, Ester. (2021). Childhood and pandemic: chronicle of an absence foretold. Salud Colectiva [Collective Health], 17. DOI: https://doi.org/10.18294/sc.2021.3303.

Massó Guijarro, Ester. (2020). Care and justice in times of coronavirus: when empathy is not enough. In E. Massó Guijarro (Ed.), Ethics and health in times of pandemic: reflections on care and social justice. Enrahonar. An International Journal of Theoretical and Practical Reason, 65: 7-14. DOI: https://doi.org/10.5565/rev/enrahonar.1313.

Massó Guijarro, Ester and Triviño Caballero, Rosana. (2020). Childbirth and abortion in times of coronavirus: the impact of the pandemic on sexual and reproductive rights. In E. Massó Guijarro (Ed.), Ethics and health in times of pandemic: reflections on care and social justice. Enrahonar. An International Journal of Theoretical and Practical Reason, 65: 117-130. DOI: https://doi.org/10.5565/rev/enrahonar.1305.

Massó Guijarro, Ester. (2018). I saved her life: the breastlived, the milk narrated. Herstories of a wet nurse, Southern Spain, 20th Century. Mana Journal. Studies in Social Anthropology, 24(3): 186-215. DOI: http://dx.doi.org/10.1590/1678-49442018v24n3p186.

Massó Guijarro, Ester. (2017a). Introduction: mythos and lógos on human lactation. Dilemata. International Journal of Applied Ethics, 25: 1-12. URL: https://www.dilemata.net/revista/index.php/dilemata/article/view/412000128/508.

Massó Guijarro, Ester. (2017b). Human lactation as living heritage: rescuing social history in the Plaza de las Pasiegas in Granada. PH Investigation: IAPH Journal for Cultural Heritage Research, 93: 10-13. DOI: https://doi.org/10.33349/revistaph.v0i0.4088.

Massó Guijarro, Ester. (2015a). Contemporary lactivism in Spain: a new socio-political tide? Journal of Spanish Cultural Studies, 1(16): 193-213. DOI: https://doi.org/10.1080/14636204.2015.1069074.

Massó Guijarro, Ester. (2015b). A lactivist ethnography: lactivist dignity through desires and politics. AIBR, 10(2): 231-257. DOI: 10.11156/aibr.100205.

Massó Guijarro, Ester. (2015c). Conjectures (and refutations?). Onbreastfeeding: decolonial breast? Dilemata. International Journal of Applied Ethics, 10(2): 185-223. URL: https://www.dilemata.net/revista/index. php/dilemata/article/view/379/384.

Massó Guijarro, Ester. (2013a). Breastfeeding and revolution, or the teat as biocultural insubordination: colostrum, body and care. Dilemata. International Journal of Applied Ethics, 11: 169-206. URL: https://www.dilemata.net/revista/index.php/dilemata/article/view/198/239.

Massó Guijarro, Ester. (2013b). Lactating desire: sexuality and politics in contemporary lactivism. Journal of Experimental Anthropology, 13: 515-529. URL: https://revistaselectronicas.ujaen.es/index.php/rae/article/ view/1841/1597.

\section{Original references in Spanish}

Hooks, b., et al. (2010). Otras inapropiables: feminismos desde las fronteras. Madrid: Traficantes de sueños.

Isasi-Díaz, Ada María. (2003). Lo cotidiano, elemento intrínseco de la realidad. In R. Fornet-Betancourt (Ed.), Resistencia y solidaridad. Globalización capitalista y liberación (pp. 365-384). Madrid: Trotta.

Massó Guijarro, Ester. (2021). Infancia y pandemia: crónica de una ausencia anunciada. Salud Colectiva, 17. DOI: https://doi.org/10.18294/sc.2021.3303.

Massó Guijarro, Ester. (2020). Cuidado y justicia en tiempos de coronavirus: cuando la empatía no basta. In E. Massó Guijarro (Ed.), Ética y salud en tiempos de pandemia: reflexiones sobre cuidados y justicia social. Enrahonar. An International Journal of Theoretical and Practical Reason, 65: 7-14. DOI: https://doi.org/10.5565/rev/enrahonar.1313.

Massó Guijarro, Ester y Triviño Caballero, Rosana. (2020). Parto y aborto en tiempos de coronavirus: el impacto de la 
pandemia en los derechos sexuales y reproductivos. In E. Massó Guijarro (Ed.), Ética y salud en tiempos de pandemia: reflexiones sobre cuidados y justicia social. Enrahonar. An International Journal of Theoretical and Practical Reason, 65: 117-130. DOI: https://doi.org/10.5565/rev/enrahonar.1305.

Massó Guijarro, Ester. (2018). Le salvé la vida: el pecho vivido, la leche narrada. Historia(s) de ama de teta, sur de España, siglo XX. Revista Mana. Estudios en Antropología Social, 24(3): 186-215. DOI: http://dx.doi.org/10.1590/1678-49442018v24n3p186.

Massó Guijarro, Ester. (2017a). Introducción: mythos y lógos sobre lactancia humana. Dilemata. Revista Internacional de Éticas Aplicadas, 25: 1-12. URL: https://www.dilemata.net/revista/index.php/dilemata/article/view/412000128/508.

Massó Guijarro, Ester. (2017b). La lactancia humana como patrimonio vivo: rescatando historia social en la Plaza de las Pasiegas de Granada. PH Investigación: revista del IAPH para la investigación del patrimonio cultural, 93: 10-13. DOI: https://doi.org/10.33349/revistaph.v0i0.4088.

Massó Guijarro, Ester. (2015a). Lactivismo contemporáneo en España: ¿una nueva marea sociopolítica? Journal of Spanish Cultural Studies, 1(16): 193-213. DOI: https://doi.org/10.1080/14636204.2015.1069074.

Massó Guijarro, Ester. (2015b). Una etnografía lactivista: la dignidad lactante a través de deseos y políticas. Revista de Antropología Iberoamericana, 10(2): 231-257. DOI: 10.11156/aibr.100205.

Massó Guijarro, Ester. (2015c). Conjeturas (¿y refutaciones?) Sobre amamantamiento: ¿teta decolonial? Dilemata. Revista Internacional de Éticas Aplicadas, 10(2): 185-223. URL: https://www.dilemata.net/revista/index.php/ dilemata/article/view/379/384.

Massó Guijarro, Ester. (2013a). Lactancia materna y revolución, o la teta como insumisión biocultural: calostro, cuerpo y cuidado. Dilemata. Revista Internacional de Éticas Aplicadas, 11: 169-206. URL: https://www.dilemata.net/revista/ index.php/dilemata/article/view/198/239.

Massó Guijarro, Ester. (2013b). Deseo lactante: sexualidad y política en el lactivismo contemporáneo. Revista de Antropología Experimental, 13: 515-529. URL: https://revistaselectronicas.ujaen.es/index.php/rae/article/ view/1841/1597. 